\title{
Wage Bargaining and Monetary Policy in a Kaleckian Monetary Distribution and Growth Model: Trying to Make Sense of the NAIRU
}

\author{
Eckhard Hein*
}

In a Kaleckian monetary distribution and growth model with conflict inflation we assess the role of a Non-Accelerating Inflation Rate of Unemployment (NAIRU). The short-run stability of a NAIRU is examined taking into account real debt effects of accelerating and decelerating inflation, and the short-run effectiveness of monetary policy interventions applying the interest rate tool is analysed. The problem of long-run endogeneity of the NAIRU is addressed integrating the long-run distribution effects of monetary policies' real interest rate variations into the model. It is concluded that monetary policy interventions in order to stabilise inflation are either unnecessary or costly in terms of employment in the short run. In the long run, these policies bear the risk of continuously increasing the NAIRU in order to keep inflation under control, which yields a horizontal long-run Phillips curve and latent stagflation. Instead of relying on monetary policies, the cause of inflation should be directly addressed and wage bargaining co-ordination should be applied as an appropriate tool.

JEL classifications: EI2, E22, E24, E25, E52

Keywords: monetary policy, wage bargaining, inflation, distribution, growth

* Macroeconomic Policy Institute (IMK) in the Hans Boeckler Foundation. This paper was presented at conferences in Berlin and Dijon in 2005 and in Bilbao and Kansas City in 2006. For helpful comments I would like to thank the participants and, in particular, Philip Arestis, Giuseppe Fontana, Geoff Harcourt, Gustav Horn, Malcolm Sawyer, Achim Truger and the referees of this journal. Remaining errors are mine.

Correspondence address:

PD Dr. Eckhard Hein, Macroeconomic Policy Institute (IMK) in the Hans Boeckler Foundation, Hans Boeckler Str. 39, 40476 Duesseldorf, Germany, e-mail: eckhard-hein@boeckler.de

Received 16 Dec 2005, accepted 11 Apr 2006

(C) INTERVENTION 3 (2), 2006, 305-329 


\section{Introduction}

The idea of a 'Non-Accelerating Inflation Rate of Unemployment ( NAIRU) is at the core of modern New Keynesian and New Consensus models of monetary policy analysis. ${ }^{.}$In these models the NAIRU is determined by structural factors of the labour market, the wage bargaining process, and the social benefit system. Due to $>$ micro-founded rigidities, short-run unemployment determined by the goods market may deviate from long-run equilibrium unemployment given by the NAIRU. However, New Keynesian and New Consensus models suppose a perhaps slow, but stable adjustment mechanism, either through a real balance effect or through a monetary policy reaction function. A downward sloping Phillips curve is valid in the short run, but in the long run effective demand and hence monetary policy has no effect on the NAIRU, and the long-run Phillips curve becomes vertical again. All that monetary policy can do is stabilising output and employment in the short run and stabilising inflation in the long run (Fontana/ Palacio-Vera 2005).

In the standard model, short-run unemployment has no effect on the NAIRU. However, within the New Keynesian approach some models have been advanced in which shortrun unemployment determined by the goods market affects the NAIRU through the phenomenon of 'hysteresis` (Blanchard / Summers 1987 and 1988, Ball 1999). Applying union wage bargaining or insider-outsider models, persistent unemployment and an increasing share of long-term unemployment in total unemployment with the associated loss of skills and access to firms by the long-term unemployed will decrease the pressure of a given rate of unemployment on labour unions' or insiders' target real wage and hence on nominal wage demands. This requires an increasing total rate of unemployment in order to stabilise inflation. The economic policy implications of this amended New Keynesian approach, however, are quite straightforward: prevent unemployment in the short run by means of applying appropriate monetary policies, and reduce the existing NAIRU by means of structural reforms in the labour market and the social benefit system, which reduce workers' nominal wage demands and hence inflation pressure, and allow for more expansive monetary policies.

Post-Keynesians have reacted differently to the New Keynesian NAIRU approach. On the one hand, some have rejected the idea of a NAIRU altogether and have insisted that unemployment in the short and in the long run is determined by the principle of

I See Carlin / Soskice (1990: I33-I66), Layard et al. (I991: 36I-396), Blanchard / Katz (I997), Stiglitz (1997), Mankiw (200I) and Ball / Mankiw (2002) for New Keynesian discussion of the NAIRU and Clarida et al. (1999), McCallum (200I), Meyer (200I), Walsh (2002), Snowdon / Vane (2005: 419427) and Carlin/ Soskice (2006: 27-172) for New Consensus models. These models are basically characterised by three equations: I. an aggregate demand function derived from households' and firms' optimisation behaviour which relates the output gap inversely to the real interest rate, 2 . an expectations-augmented Phillips curve which makes the rate of inflation positively dependent on the output gap in the short run, and 3. a central bank reaction function in which the nominal interest rate set by the central bank is determined by the equilibrium real interest rate, by the output gap, and by the deviation of actual inflation from the inflation target (Taylor rule). 
effective demand (Galbraith 1997, Davidson 1998). On the other hand, in post-Keynesian models the cause of accelerating inflation is usually attributed to unresolved conflict over the distribution of income, in particular between capital and labour (Rowthorn 1977 , Lavoie 1992: 39I-42I and 2002, Sawyer 200Ia and 2002, Cassetti 2002, Arestis / Sawyer 2004: 73-87 and 2005). This implies that, although employment is determined by effective demand in the short and in the long run, in every moment in time there may be some sort of inflation barrier ( Robinson 1962: 59) for the increase in economic activity. In what follows, we attempt to contribute to an integration of a conflicting claims theory of inflation with a long-run determination of unemployment by effective demand. This will give rise to a post-Keynesian interpretation of the NAIRU which will allow us to examine its short-run stability and long-run endogeneity properties.

Within post-Keynesian theory, Sawyer (200Ia and 2002) has argued that the NAIRU may only be a weak attractor for actual unemployment determined by effective demand without analysing the stability of the adjustment process in detail. Stockhammer (2004) has investigated the stability of the NAIRU, focussing on distribution effects of employment variations - and not on inflation effects - within a post-Keynesian distribution and growth model in the tradition of Bhaduri/Marglin (I990). He has shown that only in a profit-led growth regime the NAIRU is generally stable. Sawyer (200Ia and 2002) and Arestis / Sawyer (2004: 73-99 and 2005) have demonstrated that the NAIRU will become endogenous to actual unemployment if the long-run effects of current investment on capital stock and on productivity growth are taken into account. Lavoie's (2004) post-Keynesian amendment of the New Consensus model also relies on a positive relation between capital stock growth and productivity growth, and between output growth and labour supply, which makes the natural rate of growth and the NAIRU endogenous to actual growth and actual unemployment. ${ }^{2}$

Although post-Keynesian models of distribution and growth with conflict inflation, and also some modern New Keynesian and New Consensus NAIRU models, explicitly or implicitly rely on a credit economy in which credit and the stock of money are endogenous, they do not explicitly analyse the implications of debt and costs of debt (interest) on the stability and the endogeneity of the NAIRU. This is a serious limitation because the effects of accelerating inflation or disinflation/deflation on firms' debt-asset ratio might considerably affect their investment decisions. This has already been pointed out by Fisher (I933) and Keynes (1936: 264). Real debt effects might hence affect the stability of the NAIRU in the short run, and might contribute to endogeneity in the long run. And central banks' variations in the real interest rate, although perhaps effective in the short run when it comes to putting a halt to accelerating inflation, may have long-run effects on firms' costs of production and hence on the NAIRU which then might contradict the stabilisation of in-

2 Setterfield's (2004) post-Keynesian extension of the New Consensus model, however, assumes away an inflation barrier and hence a NAIRU. He asserts that there is a long-run stable relation between the rate of growth and the inflation rate, and hence no acceleration of inflation at a certain point. 
flation in the short run (Lavoie I992: 402-404). We will address these problems using a monetary extension of a Kaleckian model of distribution and growth, as developed in Hein (2006), and integrating conflict inflation and monetary policy interventions into this model. The remainder of the paper is structured as follows. Section 2 presents the basic model and derives the goods market equilibrium. Section 3 adds distribution conflict and inflation to the model and distinguishes the stable Inflation Rate of Employment (SIRE) from the `Goods Market Equilibrium Rate of Employment` (GERE). In Section 4 the short-run stability of the SIRE is investigated, without and with monetary policy interventions affecting the real interest rate, and it is shown that the SIRE is not generally stable. In Section 5 the long-run effects of variations in the real interest rate on the SIRE and the GERE are discussed and the endogeneity problem is addressed. Section 6 summarises and derives some conclusions for monetary policies and wage bargaining.

\section{The Basic Model}

We assume a closed economy without economic activity of the state. Under given conditions of production, there is just one type of commodity produced that can be used for consumption and investment purposes. There is a constant relation between the employed volume of labour $(L)$ and real output $(Y)$, i.e. there is no overhead labour and no technical change, so that we get a constant labour-output-ratio and hence constant labour productivity $(y)$. The capital-potential output ratio $(v)$, the relation between the real capital stock $(K)$ and potential real output $\left(Y^{v}\right)$, is also constant. The capital stock is assumed not to depreciate. The rate of capacity utilisation $(z)$ is given by the relation between actual real output and potential real output. The basic model can be described by the following equations:

$$
\begin{gathered}
p=(1+m) \frac{w}{y}, \quad m>0, \\
h=\frac{\Pi}{p Y}=1-\frac{1}{1+m}, \\
r=\frac{\Pi}{p K}=\frac{\Pi}{p Y} \frac{Y}{Y^{v}} \frac{Y^{v}}{K}=h z \frac{1}{v}, \\
\Pi=\Pi^{n}+R=\Pi^{n}+i B, \\
\lambda=\frac{B}{p K}, \\
h=h(i), \quad \frac{\partial h}{\partial i} \geq 0,
\end{gathered}
$$




$$
\begin{gathered}
\sigma=\frac{S}{p K}=\frac{\Pi-R+S_{R}}{p K}=h \frac{z}{v}-i \lambda\left(1-s_{R}\right), \quad 0<s_{R}<1, \\
g=\frac{\Delta K}{K}=\frac{I}{K}=\alpha+\beta z+\tau\left(h \frac{z}{v}-i \lambda\right), \quad \alpha, \beta, \tau>0, \quad \tau<1, \\
g=\sigma, \\
\frac{\partial \sigma}{\partial z}-\frac{\partial g}{\partial z}>0, \quad(1-\tau) \frac{h}{v}-\beta>0 .
\end{gathered}
$$

Writing $w$ for the nominal wage rate, we assume that firms set prices $(p)$ according to a mark-up $(m)$ on constant unit labour costs up to full capacity output with the mark-up being determined by the degree of price competition in the goods markets and by the relative powers of capital and labour in the labour market (equation I) (Kalecki 1954: II-27). The profit share $(b)$, i.e. the proportion of profits $(\Pi)$ in nominal output $(p Y)$, is therefore determined by the mark-up (equation 2). The profit rate $(r)$ relates the annual flow of profits to the nominal capital stock (equation 3 ).

Introducing monetary variables into the model, we follow the post-Keynesian horizontalist monetary view developed by Kaldor (1970, 1982 and 1985), Lavoie (1984, 1992: I49-216 and 1996) and Moore (1988 and 1989) and assume that the interest rate is an exogenous variable for the accumulation process whereas the quantities of credit and money are determined endogenously by economic activity. ${ }^{3}$ In this view, the central bank controls the base rate of interest. Commercial banks set the market rate of interest by marking up the base rate, and then supply the credit demand of consumers and investors they consider creditworthy at this interest rate. The central bank accommodates the necessary amount of cash. For the sake of simplicity, in what follows we suppose that the central bank's nominal interest rate policy controls - within certain limits discussed below - the real rate of interest, i.e. the nominal interest rate corrected by the inflation rate. We follow Pasinetti's (1974: 47) recommendation to treat the rate of interest as an exogenous variable in the theory of effective demand.

The pace of accumulation is determined by the entrepreneurs' decisions to invest. We assume that long-term investment finance is supplied only by retained earnings or by longterm credit of rentiers' households (directly or through banks). ${ }^{4}$ By means of this simplification we do not have to distinguish between creditor households receiving interest income, on the one hand, and shareholder households receiving dividend income, on the

3 See for a similar procedure with respect to the introduction of monetary variables into postKeynesian models of distribution and growth Lavoie (1992: 347-37I, 1993 and I995), Dutt/Amadeo (1993), Dutt (1989 and 1992), Taylor (1985 and 2004: 272-278), and Hein (1999, 2006 and 2007). 4 The distinction between short-term finance for production purposes and long-term finance for investment purposes, not dealt with in the present paper, can be found in the monetary circuit approach (Graziani 1989, 1994, Lavoie 1992: 151-169, Seccareccia 1996 and 2003). 
other hand, and their different saving propensities. ${ }^{5}$ Introducing interest payments into the model, profit splits into profit of enterprise $\left(\Pi^{n}\right)$ and rentiers' income $(R)$ (equation 4$){ }^{6}$ Rentiers' income is determined by the stock of long-term credit $(B)$ granted to firms and the exogenously given rate of interest $(i)$. Equation $(5)$ defines the firms' debt-capital-ratio $(\lambda)$.

Considering the distribution effects of interest rate variations (equation 6) we will assume that the mark-up is interest-inelastic in the short run but that it is interest-elastic in the long run. ${ }^{7}$ As the mark-up on variable costs has to cover the firms' actual and imputed interest payments, the minimum mark-up is also affected by the interest rate. For the same reason, the rate of interest determines the minimum rate of profit on real investment in the long run. In the short run, there need not be an immediate positive impact of interest rate variations on the mark-up, the profit share and the profit rate, but we rather suppose a direct effect on internal funds of the firm and hence on investment and employment, which will be discussed below. If changes in the interest rate are lasting, the mark-up and the profit share will have to change in the same direction, because in the long run firms can only sustain those production processes which yield the minimum rate of profit determined by the interest rate. Note that for a long-run effect on the mark-up and the profit share, it is a change in the interest rate and not in the actual interest payments which is relevant, because we assume that firms are aware of imputed interest costs on own capital, i.e. on accumulated retained earnings.

We assume a classical saving hypothesis, i.e. workers do not save. The part of profits retained is completely saved by definition. The part of profits distributed to rentiers' households, i.e. the interest payment, is used by these households according to their propensity to save $\left(s_{R}\right)$. Therefore, total saving $(S)$ comprises retained profits $(\Pi-Z)$ and saving out of interest income $\left(S_{R}\right)$. Taking equations (3), (4) and (5) into account, we get the saving rate $(\sigma)$ in equation $(7)$ which relates total saving to the nominal capital stock. ${ }^{8}$ Note that an increase in the rate of interest, ceteris paribus, decreases the saving rate because income is transferred from firms with a saving propensity of unity to rentiers' households with a saving propensity of less than unity. An increasing debt-capital-ratio of firms reduces the saving rate for the same reason.

Equation (8) for the accumulation rate $(g)$, relating net investment $(I)$ to the capital stock, follows the arguments in Kalecki (1954) and assumes that investment decisions are positively affected both by expected sales and by retained earnings. ${ }^{9}$ Expected sales are determined by the rate of capacity utilisation. Retained earnings, in relation to the capital

5 Of course, our simplification implies that profits net of interest payments are all reinvested into the firm.

6 In what follows the terms 'profit‘, 'profit share and 'profit rate are related to gross profits as the sum of profit of enterprise and interest paid to rentiers.

7 According to Kalecki (1954: 18), the degree of monopoly, and hence the mark-up, may but need not increase when overhead costs, including interest costs, increase.

8 This saving function is similar to the one used by Lavoie (1992: 365 and 1995: 160), the only difference is that we explicitly consider the debt-capital-ratio.

9 On different accumulation functions in Kalecki's work see also Steindl (198I). 
stock, are given by the difference between the rate of profit and the rate of interest times the debt-capital-ratio. Therefore, the rate of interest and the debt-capital-ratio both have a negative impact on investment because they adversely affect internal funds. This also limits the access to external funds on imperfect capital markets, according to Kalecki's (I937) 'principle of increasing risk.$^{\text {io }}$

The goods market equilibrium is determined by the equality of saving and investment decisions in equation (9). The goods market stability condition in equation (Io) requires that the saving rate responds more elastically to changes in capacity utilisation than capital accumulation does. Note that the necessary condition for a stable equilibrium requires that $\tau<1$, which means that the effects of internal funds on investment have to be restricted in order to achieve a stable goods market equilibrium. The goods market equilibrium values $\left(^{*}\right)$ for capacity utilisation, capital accumulation, and the rate of profit are as follows:

$$
\begin{gathered}
z^{*}=\frac{i \lambda\left(1-s_{R}-\tau\right)+\alpha}{\frac{h}{v}(1-\tau)-\beta}, \\
g^{*}=\frac{i \lambda\left[\beta\left(1-s_{R}\right)-\tau \frac{h}{v} s_{R}\right]+\alpha \frac{h}{v}}{\frac{h}{v}(1-\tau)-\beta}, \\
r^{*}=\frac{\frac{h}{v}\left[i \lambda\left(1-s_{R}-\tau\right)+\alpha\right]}{\frac{h}{v}(1-\tau)-\beta} .
\end{gathered}
$$

\section{Employment, Wage Bargaining, and Inflation: the GERE and the SIRE}

With constant productivity of labour, capacity utilisation determined by the goods market equilibrium also determines employment $(L)$ and with a given labour force $(L F)$ also the employment rate $(e=L / L F)$, which, in what follows, we term the Goods Market Equilibrium Rate of Employment (GERE). An increase in capacity utilisation is associated with a proportional increase in the GERE. Generally, in Kaleckian and post-Keynesian distribution and growth models full utilisation of productive capacity determined by the capital stock will not mean full employment of labour. In order to keep things as simple as possible, however, we will assume in what follows that the rate of capacity utilisa-

Io On Kalecki's 'principle of increasing riskı see Arestis (1996) and Sawyer (I985: IOI-IO6 and 200Ib). A similar view was taken by Robinson (1962: 86) and Steindl (1952: 107-138). Recent empirical work has shown that the interest rate has important effects on investment through its impacts on internal funds and hence on the access to external borrowing in imperfect capital markets (Fazzari et al. 1988, Hubbard 1998, Schiantarelli 1996). 
tion and the employment rate are equal $(z=e)$ and that hence full utilisation of capacity is associated with full employment. ${ }^{\text {.I }}$ Under these conditions the rate of unemployment $[u=(L F-L) / L F]$ is determined by the rate of capacity utilisation:

$$
z=e=1-u .
$$

Inflation in Kaleckian and post-Keynesian models is determined by conflict over income distribution between capital and labour. ${ }^{12}$ Figure I displays a simple sconflicting claims model of employment and inflation assuming constant production coefficients and a constant mark-up.

Although wage bargaining is concerned with money wage rates, it is assumed that labour unions intend to achieve a certain real wage rate - and with labour productivity given or productivity growth correctly anticipated a certain wage share. The labour unions' target real wage rate $\left(w_{b}^{r}\right)$ depends positively on the employment rate, and with our assumptions mentioned above therefore on the rate of capacity utilisation, because unemployment has a negative impact on union bargaining power:

$$
w_{b}^{r}=\theta+\varepsilon z .
$$

At this stage we assume that unions do not consider the macroeconomic effects of their nominal wage demands. There is neither co-ordination between unions in different firms or industries nor between wage bargaining parties and monetary policy. Full employment is therefore associated with a union target real wage rate equal to labour productivity $(y)$. Therefore, unemployment has the function to curtail distribution claims of workers (Kalecki 1971: 156-I64).

The feasible real wage rate $\left(w_{p}^{r}\right)$ is given by mark-up pricing of firms. From equation (I) we get for the rtarget real wage rater of firms:

$$
w_{p}^{r}=\frac{w}{p}=\frac{y}{1+m} .
$$

With the simplifying assumptions of a constant coefficient technology and a constant markup up to full capacity output the feasible real wage rate curve in figure $\mathrm{I}$ is just a horizontal line. The unions' target real wage and the feasible real wage only coincide by accident. From equations (I5) and (16), and making use of equation (2), we get for the employment rate $\left(e^{N}\right)$, and hence the rate of capacity utilisation $\left(z^{N}\right)$, which allows for the consistency of the target real wage rate of labour unions and firms:

$$
z^{N}=e^{N}=\frac{\frac{y}{1+m}-\theta}{\varepsilon}=\frac{y(1-h)-\theta}{\varepsilon} .
$$

II This simplification precludes that the size of the capital stock may have an effect on the NAIRU, as in Sawyer (200Ia and 2002) and Arestis/ Sawyer (2004: 71-99 and 2005).

I2 See Rowthorn (1977), Lavoie (1992: 39I-42I and 2002), Sawyer (2001a and 2002), Cassetti (2002), Arestis/ Sawyer (2004: 73-87 and 2005) for models of distribution conflict and inflation. 
Figure I: Employment Rate and Distribution Conflict - No Wage Bargaining Co-ordination

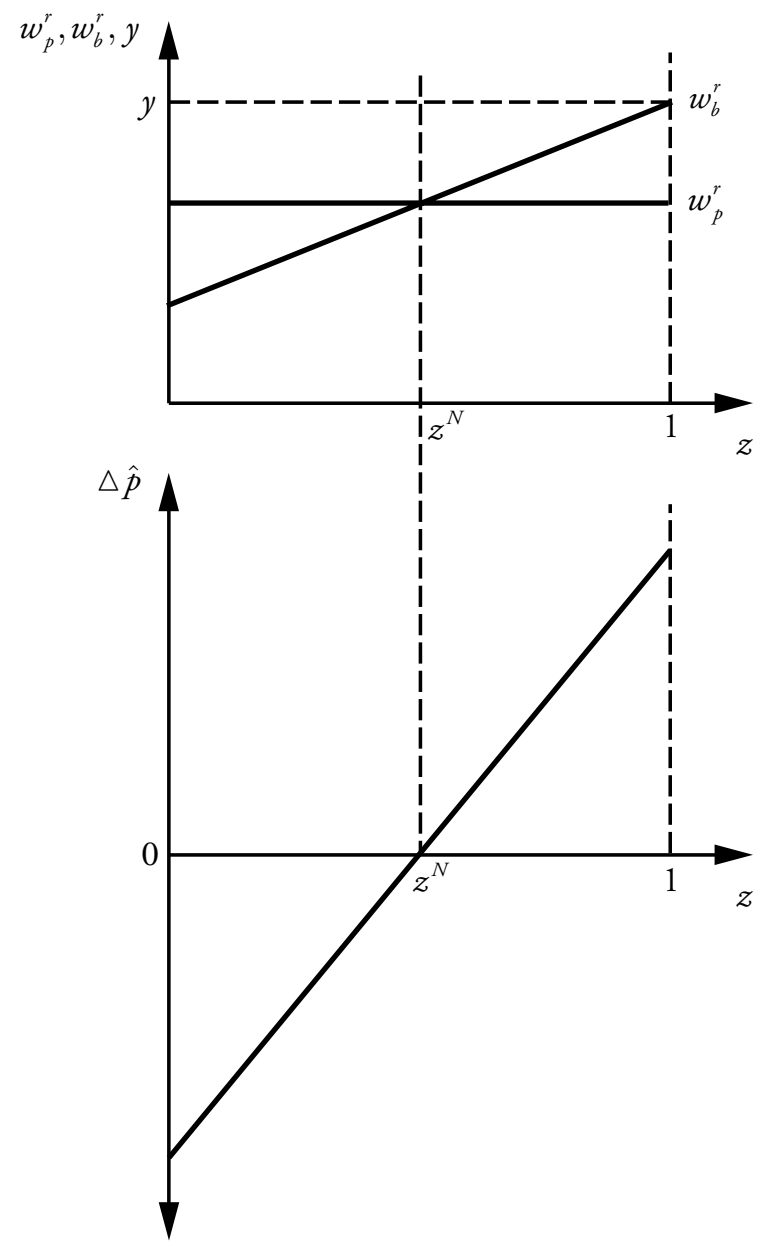

Only if the goods market equilibrium generates an employment rate of $z^{*}=z^{N}$, the distribution claims of labourers and firms will be compatible. Whenever the GERE deviates from $z^{N}$ we get rising or falling inflation rates (and finally deflation). This can easily be shown as follows. Assume that wage bargaining parties determine the growth rate of nominal wages $(\hat{w})$ according to:

$$
\hat{w}_{t}=\hat{p}_{t-1}+\hat{y}_{t}+\varepsilon\left(z_{t}^{*}-z^{N}\right) .
$$

Wage inflation is therefore determined by past inflation, (correctly anticipated) productivity growth, the attempt to improve distribution whenever the employment rate exceeds some threshold, and nominal wage moderation whenever the employment rate is below this threshold. Price setting of firms follows wage setting by wage bargainers. It is there- 
fore firms' pricing decisions which determine distribution at any rate. From equation (I) we get for the inflation rate $(\hat{p})$ :

$$
\hat{p}_{t}=(1 \hat{+} m)_{t}+\hat{w}_{t}-\hat{y}_{t}
$$

If firms do not vary the mark-up, and productivity growth is either correctly anticipated by firms and labour unions or zero, we get:

$$
\hat{p}_{t}=\hat{p}_{t-1} \text {, only if: } z_{t}^{*}=z^{N}=1-N A I R U .
$$

The unemployment rate $\left[u^{N}=\left(L F-L^{N}\right) / L F=1-e^{N}=1-z^{N}\right]$ associated with this 'Stable Inflation Rate of Employment`(SIRE) may therefore be termed `Non-Accelerating Inflation Rate of Unemployment` (NAIRU). It defines a distribution equilibrium between the claims of workers and those of firms.

\section{The Short-run Stability of the NAIRU/the SIRE}

Discussing the stability of the NAIRU or the SIRE we will proceed in two steps. First, we will consider the issue of stability without monetary policy interventions. Then we will analyse the effects of monetary policy applying the interest rate tool whenever the GERE deviates from the SIRE.

\section{I No Monetary Policy Intervention}

In older New Keynesian models with an exogenous stock of money, the stability of the NAIRU is achieved by a real balance effect. ${ }^{13}$ Falling (rising) nominal wage and hence price inflation whenever unemployment is above (below) the NAIRU is assumed not to affect nominal demand but only real demand. This will then bring back real demand to a level consistent with the NAIRU. However, as in our model the stock of money is endogenous, Keynes and/or Pigou effects cannot work as stabilisers.

Stockhammer (2004) has discussed another potential stabilisation mechanism of the NAIRU in a post-Keynesian distribution and growth model making use of the Bhaduri/ Marglin (1990) distinction between wage-led and profit-led growth regimes. Following a suggestion by the late Kalecki (I971: 156-I64), distribution is assumed to be affected by unemployment: rising (falling) unemployment causes a falling (rising) wage share. Therefore, in a profit-led regime the NAIRU will always be stable, whereas in a wage-led regime stability depends on the relative adjustments of accumulation and distribution whenever unemployment deviates from the NAIRU. However, the distribution effects of a changing employment rate or rate of capacity utilisation supposed by Stockhammer (2004) can-

I3 See Carlin / Soskice (1990: 159-160), and Layard et al. (1991: 362-364) who rely on a Keynes effect within an IS-LM-framework. Blanchard/Summers (1987) take nominal demand as given and implicitly rely on a Pigou effect. 
not be taken for granted: a rising employment rate will cause increasing nominal wage demands by workers, but it may also trigger rising profit claims by firms and hence rising mark-ups. ${ }^{14}$ And as firms set prices in the goods markets after nominal wages have been set in the labour market, we could also suppose a rising profit share accompanying rising rates of capacity utilisation and employment due to firms' improved sales conditions, at least in a closed economy. If this is assumed, the NAIRU in Stockhammer's (2004) model will be stable in the wage-led regime, whereas in the profit-led regime stability will depend on relative adjustments of accumulation and distribution.

We will not try to resolve this issue here and continue to assume that distribution between wages and gross profits is not affected by changes in the rates of capacity utilisation and employment. In what follows we will rather discuss a presumably more important effect in a credit economy: the real debt effect associated with rising/ falling inflation rates which has already been highlighted by Fisher (1933) and by Keynes (I936: 264).

Let us assume that the stock of firms' debt is not indexed to changes in the inflation rate. Accelerating inflation will therefore decrease the debt-capital-ratio defined in equation (5), decelerating inflation will increase this ratio. If monetary policy does not respond to changes in the inflation rate, and does not vary the nominal interest rate accordingly, real interest rates will fall in the face of accelerating inflation and will rise when inflation decelerates. Taken together, this implies that the interest-capital-ratio $[i \lambda=(i B) /(p K)=R /(p K)]$ will fall when inflation rises, and will rise when inflation falls. Given that changes in the real interest rate do not affect the mark-up and hence the profit share in the short run, the effects of changes in the interest-capital-ratio on the GERE can be determined from equation (II):

$$
\frac{\partial z}{\partial(i \lambda)}=\frac{1-s_{R}-\tau}{\frac{h}{v}(1-\tau)-\beta} .
$$

If only stable goods market equilibria are considered, equation (IIa) shows that the effects of changes in the interest-capital-ratio on the GERE depend on the parameters in the saving and investment function of the model. If the rentiers' propensity to consume $\left(1-s_{R}\right)$ is smaller than firms' investment elasticity related to internal funds $(\tau)$, rising indebtedness and rising real interest payments will have a negative effect on the GERE. This can be called the snormal case (Lavoie 1995), usually expected in post-Keynesian theory. An increasing interest-capital-ratio of firms will have a negative impact on the goods market equilibrium. If the conditions of the snormal case prevail, the SIRE will be unstable. Whenever the GERE exceeds the SIRE, accelerating inflation will cause falling debt-capital-ratios and falling real interest rates, and hence a rising GERE, moving the economy farther away from stable inflation. If the GERE falls short of the SIRE, decelerating inflation and finally deflation will cause a rising debt-capital-ratio and rising real interest rates,

I4 See Arestis / Sawyer (2004: 73-87 and 2005) for a conflicting claims model with an increasing mark-up when high levels of capacity utilisation are achieved. See also Lavoie (1992: 391-397) for a discussion of different cases with respect to relative bargaining power of firms and labour unions. 
and hence a falling GERE. The economy will be trapped in a downward spiral of disinflation/deflation, rising real indebtedness of the firm sector and a falling GERE. Therefore we get a macroeconomic sparadox of debt ‘ associated with cumulative inflation or disinflation/deflation. ${ }^{\text {Is }}$ With decelerating inflation and rising interest-capital-ratios, firms individually reduce investment in order to confine the burden of debt, with the macroeconomic effect that disinflation or deflation is reinforced and the interest-capital-ratio keeps on rising. With accelerating inflation, firms individually will increase debt and investment, with the macroeconomic effect of further acceleration of inflation and a further decrease in the interest-capital-ratio.

If the rentiers' propensity to consume exceeds firms' investment elasticity with respect to internal funds, a rising interest-capital-ratio of firms will be associated with an increasing GERE. This may be called the spuzzling case (Lavoie I995), usually not expected in post-Keynesian theory. If the conditions of the spuzzling case prevail, the SIRE will be stable. Rising (falling) inflation rates will trigger falling (rising) debt-capital-ratios and falling (rising) real interest rates which will then cause a falling (rising) GERE. ${ }^{16}$ The GERE will therefore adjust to the SIRE.

\subsection{Monetary Policy Intervention}

In our `normal case`, stabilising the SIRE requires monetary policy intervention applying the monetary interest rate tool. Also modern New Keynesian and, in particular, the New Consensus models rely on monetary policy to adjust actual unemployment to the NAIRU and to stabilise the inflation rate. ${ }^{17}$ In these models the (real) rate of interest is the monetary policy instrument which implies that it is no longer assumed that monetary policy controls the stock of (high-powered) money and that the latter is endogenous to the whole economic process (Arestis / Sawyer 2004: IO-72). Whenever unemployment falls short of the NAIRU, and inflation accelerates, the central bank is supposed to increase nominal interest rates such that real interest rates increase, which then adversely affects aggregate demand and hence employment. If unemployment is above the NAIRU the central bank should lower nominal interest rates such that real interest rates decrease, which increases aggregate demand and hence employment. In order to have a stable NAIRU, monetary

I5 For a macroeconomic paradox of debt in Kaleckian and post-Kaleckian distribution and growth models with constant prices see Lavoie (1995) and Hein (2006 and 2007).

I6 Even if we concede that in the face of accelerating inflation the behaviour of rentiers and firms may change, this will only temporarily inhibit the convergence process of the GERE towards the SIRE. Rentiers' consumption behaviour may change and the saving propensity out of rentiers' income may decline when inflation accelerates. For the spuzzling case to exist, however, the saving propensity of rentiers already has to be very low so that there is only small room for manoeuvre. The same argument applies to the responsiveness of investment with respect to interest payments.

I7 For the modern New Keynesian and New Consensus view see Clarida et al. (1999), Romer (2000), Taylor (2000), McCallum (200I), Meyer (200I), Walsh (2002), Snowdon/Vane (2005: 419-427), and Carlin / Soskice (2006: 27-172). 
policy interventions have to be symmetric and their effects have to be assumed to be symmetric as well. If these conditions are fulfilled, what central banks can achieve is output stabilisation in the short run and stable inflation rates in the long run (Fontana/PalacioVera 2005). ${ }^{18}$

In the snormal case in our model, however, in order to stabilise the SIRE central banks do not only have to change real rates of interest by means of varying the nominal rate, but the change in the real interest rate has to be sufficient to overcompensate the counter-effects of the change in the debt-capital-ratio of firms on the GERE. In general, this is not a problem in a situation of rising inflation, because there is no upper limit for the nominal interest rate set by the central bank. But in a situation of falling inflation or even deflation, central banks may not be able to reduce the nominal rate of interest by a sufficient amount to decrease real rates and to overcompensate the restrictive demand effects of rising debt-capital-ratios, because there is a zero lower bound for the nominal interest rate. Therefore, in this situation central banks may be unable to adjust the GERE to the SIRE, and the economy may be trapped in a deflationary recession. In the snormal case, therefore, the NAIRU can generally only be considered an inflation barrier which has to be enforced by the central banks, but central banks may be incapable to adjust actual unemployment to the NAIRU whenever the former exceeds the latter.

In the spuzzling case`, monetary policy interventions, which follow the New Keynesian / New Consensus advice and increase the real rate of interest in the face of rising inflation and decrease it in the face of falling inflation or deflation, will have a destabilising effect. This may overcompensate the stabilising effect exerted by the change in the debtcapital-ratio and may cause a further deviation of the GERE from the SIRE. Table I summarises our results with respect to short-run stability of the SIRE.

Table I: The Short-run Stability of the Stable Inflation Rate of Employment (SIRE)

\begin{tabular}{l|ll}
\hline & \multicolumn{1}{|c}{$\begin{array}{c}-1-s_{R}-\tau \\
\text { ('normal case') }\end{array}$} & \multicolumn{1}{c}{$\begin{array}{c}+ \\
\text { ('puzzling case') }\end{array}$} \\
\hline $\begin{array}{l}\text { No monetary policy } \\
\text { intervention }\end{array}$ & unstable & \multicolumn{1}{|c}{ stable } \\
$\begin{array}{l}\text { Monetary policy } \\
\text { intervention }\end{array}$ & $\begin{array}{l}\text { stable, } \\
\text { if change in real interest rate } \\
\text { overcompensates change in the } \\
\text { debt-capital-ratio, } \\
\text { otherwise unstable }\end{array}$ & $\begin{array}{l}\text { unstable, } \\
\text { if change in real interest rate } \\
\text { overcompensates change in the } \\
\text { debt-capital-ratio, } \\
\text { otherwise stable }\end{array}$ \\
\hline
\end{tabular}

I8 For a more extensive discussion of the New Consensus model from a post-Keynesian view see Arestis / Sawyer (2004), Lavoie (2004), Setterfield (2004), Fontana/ Palacio-Vera (2005), and PalacioVera (2005). 


\section{The Long-run Endogeneity of the NAIRU/ the SIRE}

The endogeneity of the NAIRU, that is the adjustment of the NAIRU to the actual rate of unemployment determined by the goods market in the case of a persistent deviation of the two rates, has been discussed within New Keynesian models under the heading of 'hysteresis` (Blanchard/Summers 1987, Ball 1999). Applying union wage bargaining or insider-outsider models, persistent unemployment and an increasing share of long-term unemployment in total unemployment with the associated loss of skills and access to firms by the long-term unemployed will decrease the pressure of a given rate of unemployment on labour unions' or insiders' target real wage and hence on nominal wage demands. The labour unions' target real wage curve in figure I (p. 313) will rotate upwards ( $\varepsilon$ in equations (I5), (I7) and (I8) will increase), the SIRE will decline, and the NAIRU will increase.

Sawyer (200Ia and 2002) and Arestis / Sawyer (2004: 73-99 and 2005) have discussed another source of endogeneity of the NAIRU: the effect of current investment on capital stock and productivity growth. ${ }^{19}$ Whereas investment in the short run determines effective demand and hence the GERE, net investment also increases the capital stock and therefore affects maximum employment if it is restrained by the capital stock. And it also affects the NAIRU or the SIRE if it is assumed that firms increase the mark-up when actual output approaches full capacity output. In order to simplify our model, we have excluded this by means of assuming a constant mark-up and full utilisation of capital stock being associated with full employment. However, in the real world this is not necessarily the case and Arestis / Sawyer have therefore made an important point: low investment does not only cause a low GERE, but also decreases the SIRE by restraining the capital stock and output capacity. But investment does not only affect the size of the capital stock, it also affects productivity growth if we assume that technical progress is embodied in physical investment and/or that there are increasing returns to scale. ${ }^{20}$ In our model, increasing productivity (growth) will shift the firms' target real wage curve in figure I downwards and the SIRE in equation (I7) will increase. This, however, supposes that labour unions do not adjust their target real wage rate when productivity growth increases. But this cannot be taken for granted, if labour unions target a certain wage share and can correctly anticipate productivity growth as we have assumed in equation (I8). If this is the case, productivity growth will have no effect on the SIRE or the NAIRU. Therefore, the effect of productivity growth on the NAIRU depends on labour unions' or workers' aspirations to participate in increasing productivity.

I9 See also Rowthorn (1995 and 1999), Arestis / Biefang-Frisancho Mariscal (2000) and Arestis et al. (2006).

20 The productivity-enhancing effects of investment in capital stock is pointed out in demandled growth models; see Kaldor (I957), Leon-Ledesma/Thirlwall (2002), Dutt (2003 and 2006), and the papers in Setterfield (ed.) (2002). Growth is primarily demand-driven because labour force and productivity growth respond to demand. This view has been applied by Lavoie (2004) in his postKeynesian alternative to the New Consensus models in which the natural rate of growth is endogenous to the actual rate of growth. 
In what follows we will trace another source of endogeneity which is associated with the distributional effects of monetary policy responses to accelerating or decelerating inflation rates. Assume for the reasons given above that persistent changes in the real interest rate are in the long run accompanied by changes in the mark-up in the same direction. In our model this has two effects.

First, changes in the mark-up affect the firms' target real wage rate: an increasing (decreasing) mark-up shifts the firms' target real wage curve in figure I downwards (upwards) and the SIRE decreases (increases). From equation (I7) we get for the effect of a change in the mark-up and hence in the profit share on the SIRE:

$$
\frac{\partial z^{N}}{\partial h}=-\frac{y}{\varepsilon}<0 .
$$

Second, changes in the mark-up and thus in distribution between wages and gross profits have an additional effect on the goods market equilibrium and hence on the GERE. From equation (II) we get:

$$
\frac{\partial z}{\partial h}=-\frac{\frac{1-\tau}{v} z}{\frac{h}{v}(1-\tau)-\beta}<0 .
$$

The effect of a change in the mark-up and in the profit share on the GERE is negative. Raising the mark-up when interest rates increase will have a positive impact on firms' internal funds but will simultaneously reduce consumption demand, sales and hence capacity utilisation (and the GERE), which will then negatively feed back on internal funds. Furthermore, lower capacity utilisation will also have a negative impact on investment decisions.

Let us now discuss the implications for the effects of monetary policy interventions. We start with the snormal case from table I (p. 3I7). Assume that the GERE exceeds the initial SIRE at $z_{1}^{N}$ in figure 2 (p. 32I). Since accelerating inflation and a falling interestcapital-ratio of firms is a stimulus for effective demand, the GERE will further increase and inflation acceleration will speed up. In order to stabilise the rate of inflation, central banks have to increase nominal interest rates in order to raise real interest rates by a sufficient amount to overcompensate the demand stimulating effects of falling debt-capitalratios. Therefore, in the short run the central bank can bring back the GERE to the SIRE at $z_{1}^{N}$. In the long run, however, a higher real interest rate will induce firms to increase the mark-up. This will shift the firms' target real wage curve down from $w_{p 1}^{r}$ to $w_{p 2}^{r}$ and reduce the SIRE to $z_{2}^{N}$. The redistribution at the expense of labour will also reduce the GERE. Three scenarios are possible depending on the relative effects of changes in distribution on the GERE and on the SIRE in equations (IIb) and (I7a).

I. If, by accident, ${ }^{\partial z} / \partial h=\partial z^{N} / \partial h$, the reduction of the GERE caused by an increasing markup will make this new rate coincide with the SIRE at $z_{2}^{N}$ so that the economy gets to rest at a stable SIRE. 
2. If $|\partial z / \partial h|>\left|\partial z^{N} / \partial h\right|$, the effective demand effect of redistribution at the expense of labour will make the GERE fall below $z_{2}^{N}$ and we get falling inflation rates. This should then make monetary policies reduce real interest rates, making the GERE increase to $z_{2}^{N}$ in the short run. In the long run, firms then reduce mark-ups, the firms' target real wage curve shifts upwards, and effective demand is stimulated by redistribution in favour of labour. The SIRE as well as the GERE will increase, with the latter now overshooting the former, and monetary policy will have to intervene again. This oscillation may converge to a stable SIRE between $z_{2}^{N}$ and $z_{1}^{N}$, but may also generate stable oscillation around that SIRE, or the oscillation may even explode, depending on the degree of over- and undershooting of the GERE with respect to the SIRE and the concomitant change in the real interest rate required for the short-run adjustment of the GERE to the SIRE.

3. If $|\partial z / \partial h|<\left|\partial z^{N} / \partial h\right|$, the effective demand effect of redistribution at the expense of labour is weak so that the GERE remains above $z_{2}^{N}$. We will get accelerating inflation again inducing the central bank to increase real interest rates, forcing the GERE down to $z_{2}^{N}$ in the short run. In the long run, firms will again increase mark-ups, which will shift their target real wage curve down to $w_{p 3}^{r}$, and the SIRE will decline to $z_{3}^{N}$. The GERE will also decline because of the redistribution of income at the expense of labour, but will remain above $z_{3}^{N}$, inflation will accelerate anew and central banks will have to intervene again.

Equation (IIb) shows that the effective demand effect of redistribution between wages and gross profits becomes weaker when the GERE decreases. This implies that a development according to scenario 3 becomes the more likely the lower the GERE declines. This is shown in figure 2: stable inflation is associated with a declining SIRE. The long-run ,Phillips curve becomes horizontal because of the nature of monetary policy interventions. ${ }^{2 \mathrm{I}}$ In this scenario, monetary policy is only able to stabilise the inflation rate in the long run at the expense of a continuously decreasing GERE. Monetary policy interventions trigger a process in which stabilising inflation in the short run by means of increasing real interest rates and slowing down the economy re-establishes the inflation problem in the long run when the full distribution effects of real interest rate variations are felt. In the long run, this scenario describes a latent tendency towards stagflation.

Note that scenario 3 also works in reverse: if the central bank intends to improve the GERE, in the short run lowering real interest rates will be associated with accelerating inflation. In the long run, however, a falling mark-up increases the SIRE. And since the demand effect of redistribution in favour of labour is not too strong so that the GERE does not exceed the SIRE, there is again room for manoeuvre for the central bank to cut real interest rates.

2I Our argument is different from Freedman et al.'s (2004) who also derive a horizontal long-run Phillips curve. They use the labour market hysteresis argument: In order to keep inflation down, a certain amount of short-term unemployment is required irrespective of long-term unemployment. But as short-term unemployed in the process of time inevitably become long-term unemployed, the total rate of unemployment required to stabilise inflation has to increase. 
Figure 2: Long-run Endogeneity of the stable Inflation Rate of Employment, (SIRE) Caused by Monetary Policy Intervention - The Horizontal ,Long-run Phillips Curver

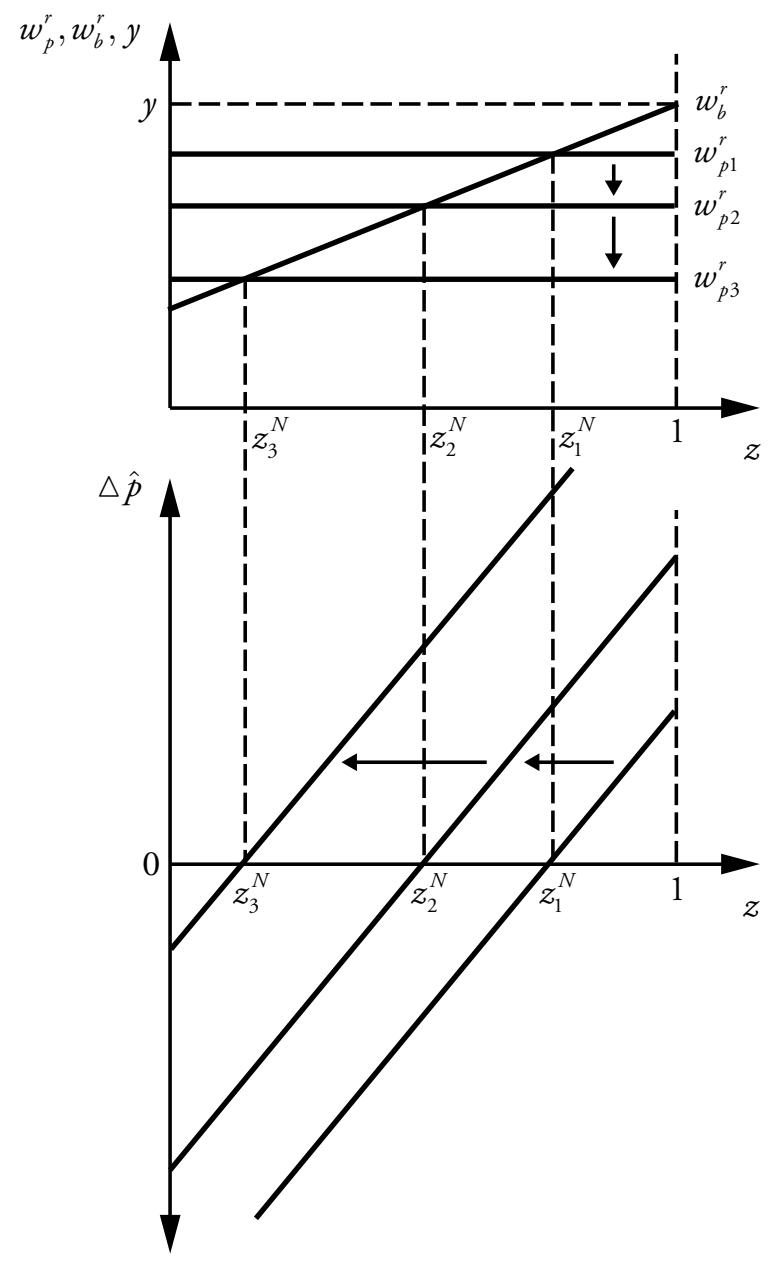

Let us now briefly discuss the short-run spuzzling` case from table I. In this case a deviation of the GERE from the SIRE is self-correcting in the short run without monetary policy intervention. If the GERE exceeds $z_{1}^{N}$ in figure 2, the reduction in consumption demand caused by the devaluation of rentiers' assets will overcompensate the stimulation of firms' investment demand caused by a falling interest-capital-ratio. If central banks simply hold the nominal interest rate constant, they will support this adjustment process and the economy will approach $z_{1}^{N}$.

If, however, central banks try to fight accelerating inflation rates by means of increasing the real interest rate as recommended by the New Keynesian and the New Consensus 
models, they will delay the convergence process towards $z_{1}^{N}$ in the short run. ${ }^{22}$ The longrun effect of an increasing real interest rate will reduce the SIRE to $z_{2}^{N}$. This will again accelerate inflation. The redistribution at the expense of labour caused by an increasing markup, however, will have a dampening effect on the GERE shifting it towards $z_{2}^{N}$. Again, we have three scenarios depending on the relative effects of changes in distribution on the GERE and on the SIRE (equations (rib) and (I7a)):

I. If, by accident, $\partial z / \partial h=\partial z^{N} / \partial h$, the GERE will coincide with $z_{2}^{N}$ and the economy will get to rest in this lower stable SIRE.

2. If $|\partial z / \partial \phi|>\left|\partial z^{N} / \partial \phi\right|$, the GERE falls below $z_{2}^{N}$ and we will get disinflation, short-run real interest rate cuts delaying the convergence process towards $z_{2}^{N}$, which will in the long run decrease the mark-up moving the SIRE upwards. Redistribution in favour of labour will stimulate demand and employment and will make the GERE exceed the SIRE, and so on. The outcome of this process will again depend on the degree of over- and undershooting of the GERE with respect to the SIRE and on the degree of (now disturbing) monetary policy interventions.

3. If $|\partial z / \partial h|<\left|\partial z^{N} / \partial h\right|$, the redistribution effect at the expense of labour income on demand is weak, the GERE will remain higher than $z_{2}^{N}$. Inflation will accelerate, central banks will increase real interest rates disturbing the short-run convergence process towards $z_{2}^{N}$ and decreasing the SIRE to $z_{3}^{N}$.

Since the effective demand effect of redistribution between wages and gross profits becomes weaker when the employment rate goes down (equation (IIb)), we get again that scenario 3 becomes the more likely the lower the GERE drops: The long-run >Phillips curver becomes again horizontal, as in figure 2.

Let us finally add that, whatever case we consider and whatever scenario comes into existence, in the long run the SIRE and hence the NAIRU are endogenous to monetary policy's real interest rate manipulation in our model. Therefore, in our approach the NAIRU is a direct result of monetary policy interventions.

\section{Results and Implications for Monetary Policy and Wage Bargaining}

In a Kaleckian distribution and growth model with endogenous money and inflation generated by distribution conflict we have shown that monetary policy is either an unnecessary or a costly tool to control inflation in the short run. Taking into account the real debt effects of inflation acceleration or deceleration, the NAIRU will be stable in the spuzzling, case with a propensity to consume out of rentiers' income exceeding the sensitivity of investment with respect to internal funds. Inflation targeting monetary policies raising real interest rates in the face of accelerating inflation will disturb adjustment to stable inflation

22 Of course, central banks raising the real interest rates may also prevent the adjustment process as we have argued above. 
rates in this case. In the snormal case of a rentiers' propensity to consume falling short of firms' elasticity of investment with respect to internal funds, the NAIRU will be unstable. Inflation targeting monetary policies applying the interest rate tool will be able to contain accelerating inflation. There are, however, some doubts whether monetary policies will be able to fight decelerating inflation and finally deflation because there is a zero bound for the nominal interest rate. In this case, therefore, the NAIRU is merely an inflation barrier enforced by monetary policies, but there is no guarantee that monetary policies will always be able to adjust unemployment determined by the goods market to the NAIRU, as is assumed in New Keynesian or New Consensus models.

In the long run, variations in the real interest rate will affect the firms' target real wage rate and the NAIRU becomes endogenous to monetary policy. This direct channel of endogeneity supplements those channels already discussed in the literature: labour market hysteresis and capital stock effects on the NAIRU. In the snormal as well as in the spuzzling case, inflation targeting monetary policies raising the real interest rate in the face of accelerating inflation will raise the NAIRU. This bears the risk of a continuously increasing NAIRU in order to keep inflation under control, which may yield a horizontal long-run Phillips curve and latent stagflation. Taking these effects into account, monetary policy raising real interest rates can be considered an inappropriate tool to control inflation in the long run.

According to our analysis, monetary policy should rather aim at low real interest rates in the short and in the long run. This allows for a long-run increase in the SIRE and hence a reduction in the NAIRU, in any case. In the spuzzling case, lower real interest rates will decrease the GERE in the short run, but the real debt effects associated with disinflation will finally adjust the GERE to the higher SIRE in the long run. In the snormal case, lowering real interest rates will increase the GERE in the short run which might trigger acceleration of inflation. This, however, will be dampened or even be wiped out as soon as the long-run increase in the SIRE becomes effective.

If short-run accelerating inflation in the face of an increasing GERE is to be avoided, the causes of inflation should directly be addressed. Therefore, policy makers should resort to wage bargaining co-ordination as an appropriate tool. As recent research on the interaction of independent central banks and wage bargaining institutions has shown, effectively co-ordinated wage bargaining is able to internalise negative macroeconomic wage externalities (Franzese 200Ia and 200Ib, Hein 2002 and 2004): in economies with a high degree of reffectiver wage bargaining co-ordination, the reduction of inflation rates has been accompanied by less employment losses than in economies with a low degree of co-ordination. Effective wage bargaining co-ordination is characterised by a high degree of horizontal bargaining co-ordination between industries (pattern bargaining, state imposed or sponsored co-ordination, intra-associational co-ordination). In order to solve the implementation problem of collective agreements and to prevent wage dumping or positive wage drift, reffective bargaining co-ordination also has to include a high degree of vertical co-ordination within industries (high level of union and bargaining agreement coverage, legal enforceability of collective agreements, peace obligations) (Kittel/Traxler 
200I). The influence of effective co-ordination of wage bargaining on the SIRE in our model is shown in figure 3 .

\section{Figure 3: Employment Rate and Distribution Conflict- Effective Wage Bargaining Co-ordination}

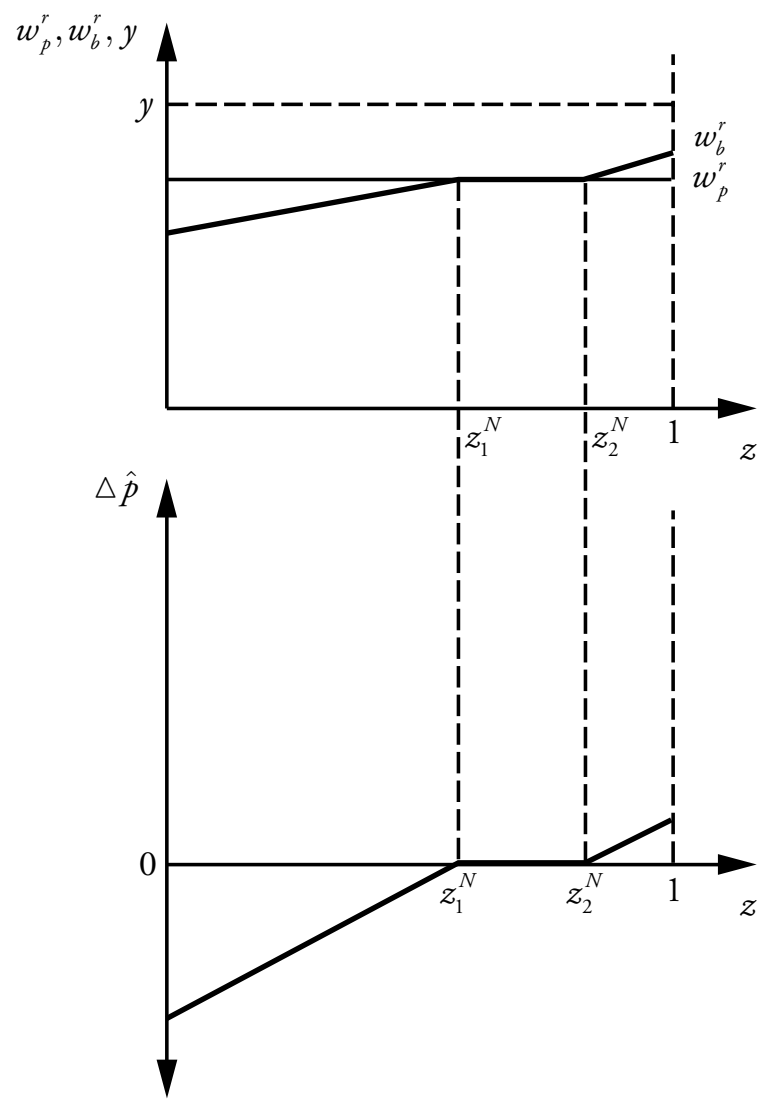

With effective wage bargaining co-ordination, the labour unions' target real wage curve has a horizontal part. Between $z_{1}^{N}$ and $z_{2}^{N}$ the bargaining parties are able to accept the feasible real wage and to exhaust the scope for distribution, taking into account the inflation objective of the central bank. By means of effectively co-ordinated wage bargaining a constant inflation rate becomes compatible with a range of GEREs. The SIRE or the NAIRU as the short-run limit to employment are no longer unique. Contrary to prevailing propositions, in our Kaleckian approach a reduction of the NAIRU and an increase in the SIRE can be attained by means of organising the labour market and co-ordinating the bargaining parties, and does not require decentralisation of wage bargaining and deregulation of labour markets, as in New Keynesian or New Consensus models. A high degree of effective wage 
bargaining co-ordination should also have the additional virtue that increasing unemployment will not cause immediate disinflation or deflation with its potentially negative impacts on effective demand and the GERE in the snormal case of our model.

\section{References}

Arestis, Philip (1996): Kalecki’s Role in Post Keynesian Economics: An Overview, in: King, John E. (ed.), An Alternative Macroeconomic Theory: The Kaleckian Model and PostKeynesian Economics, Boston: Kluiwer, pp. II-34

Arestis, Philip / Baddeley, Michelle/ Sawyer, Malcolm (2006): Is Capital Stock a Determinant of Unemployment?, in: Hein, Eckhard / Heise, Arne/Truger, Achim (eds.), Wages, Employment, Distribution and Growth. International Perspectives, Basingstoke: Palgrave/ Macmillan, pp. 49-66

Arestis, Philip/ Biefang-Frisancho Mariscal, Iris (2000): Capital Stock, Unemployment and Wages in the UK and Germany, in: Scottish Journal of Political Economy, Vol. 47, No. 5, pp. 487-503

Arestis, Philip / Sawyer, Malcolm (2004): Re-examining Monetary and Fiscal Policy for the $2 \mathrm{I}^{\text {st }}$ Century, Cheltenham: Edward Elgar

Arestis, Philip/Sawyer, Malcolm (2005): Aggregate Demand, Conflict and Capacity in the Inflationary Process, in: Cambridge Journal of Economics, Vol. 29, No. 6, pp. 959974

Ball, Laurence (1999): Aggregate Demand and Long-run Unemployment, in: Brooking Papers on Economic Activity, No. 2, pp. 189-25I

Ball, Laurence/ Mankiw, N. Gregory (2002): The NAIRU in Theory and Practice, in: Journal of Economic Perspectives, Vol. 16, No. 4, pp. II5-136

Bhaduri, Amit/ Marglin, Stephen (1990): Unemployment and the Real Wage: The Economic Basis for Contesting Political Ideologies, in: Cambridge Journal of Economics, Vol. I4, No. 4, pp. 375-393

Blanchard, O., Katz, L. F. (1997): What We Know and Do Not Know About the Natural Rate of Unemployment, in: Journal of Economic Perspectives, Vol. II, No. I, pp. 5I-72

Blanchard, Oliver/Summers, Lawrence H. (1987): Hysteresis in Unemployment, in: European Economic Review, Vol. 3I, No. I-2, pp. 288-295

Blanchard, Oliver/Summers, Lawrence H. (1988): Beyond the Natural Rate Hypothesis, in: American Economic Review, Vol. 78, No. 2, pp. 182-187

Carlin, Wendy/Soskice, David (1990): Macroeconomics and the Wage Bargain. A Modern Approach to Employment, Inflation and the Exchange Rate, Oxford: Oxford University Press

Carlin, Wendy/Soskice, David (2006): Macroeconomics. Imperfections, Institutions and Policies, Oxford: Oxford University Press

Cassetti, Mario (2002): Conflict, Inflation, Distribution and Terms of Trade in the Kaleckian Model, in: Setterfield, Mark (ed.), The Economics of Demand-led Growth, Cheltenham: Edward Elgar, pp. I89-2II 
Clarida, Richard / Gali, Jordi / Gertler, Mark (1999): The Science of Monetary Policy: A New Keynesian Perspective, in: Journal of Economic Literature, Vol. 37, No. 4, pp. 166I-1707 Davidson, Paul (1998): The Macroeconomics of OECD Unemployment, in: The Economic Journal, Vol. I08, No. 448, pp. 8I7-83I

Dutt, Amitava K. (1989): Accumulation, Distribution and Inflation in a Marxian / Post-Keynesian Model with a Rentier Class, in: Review of Radical Political Economics, Vol. 2I, No. 3, pp. $18-26$

Dutt, Amitava K. (1992): Rentiers in Post-Keynesian Models, in: Arestis, Philip/Chick, Victoria (eds.), Recent Developments in Post-Keynesian Economics, Aldershot: Edward Elgar, pp. 95-I22

Dutt, Amitava K. (2003): New Growth Theory, Effective Demand, and Post-Keynesian Dynamics, in: Salvadori, Neri (ed.), Old and New Growth Theories: An Assessment, Cheltenham: Edward Elgar, pp. 67-100

Dutt, Amitava K. (2006): Aggregate Demand, Aggregate Supply and Economic Growth, in: International Review of Applied Economics, Vol. 20, No. 3, pp. 319-336

Dutt, Amitava K. / Amadeo, Edward J. (1993): A Post-Keynesian Theory of Growth, Interest and Money, in: Baranzini, Mauro/Harcourt Geoffrey C. (eds.), The Dynamics of the Wealth of Nations, London: Macmillan, pp. I8I-205

Fazzari, Steven M. / Hubbard, R. Glenn / Petersen, Bruce C. (1988): Financing Constraints and Corporate Investment, in: Brooking Papers on Economic Activity, No. I, pp. I4I-I95

Fisher, Irving (1933): The Debt-Deflation Theory of Great Depressions, in: Econometrica, Vol. I, No. 4, pp. 337-357

Fontana, Giuseppe / Palacio-Vera, Alfonso (2005): Are Long-run Price Stability and Short-run Output Stabilization All That Monetary Policy Can Aim for?, The Levy Economic Institute of Bard College Working Paper, No. 430

Franzese, Robert J. (200Ia): Institutions and Sectoral Interactions in Monetary Policy and Wage / Price-Bargaining, in: Hall, Peter A. / Soskice, David (eds.), Varieties of Capitalism. Institutional Foundations of Comparative Advantage, Oxford: Oxford University Press, pp. IO4-I44

Franzese, Robert J. (200Ib): Strategic Interaction of Monetary Policymakers and Wage/ Price Bargainers: A Review With Implications for the European Common-Currency Area, in: Empirica, Vol. 28, No. 4, pp. 457-486

Freedman, Craig/ Harcourt, Geoffrey C. / Kriesler, Peter (2004): Has the Long-run Phillips Curve Turned Horizontal?, in: Argyrous, George / Forstater, Matthew / Mongiovi, Gary (eds.), Growth, Distribution, and Effective Demand. Alternatives to the Orthodoxy. Essays in Honor of Edward J. Nell, Armonk, New York: M.E. Sharpe, pp. I44-I62

Galbraith, James K. (1997): Time to Ditch the NAIRU, in: Journal of Economic Perspectives, Vol. II, No. I, pp. 93-I08

Graziani, Augusto (1989): The Theory of the Monetary Circuit, in: Thames Papers in Political Economy, Spring

Graziani, Augusto (1994): Monetary Circuits, in: Arestis, Philip/Sawyer, Malcolm (eds.), The Elgar Companion to Radical Political Economy, Aldershot: Edward Elgar, pp. 274-278 
Hein, Eckhard (1999): Interest Rates, Income Shares and Investment in a Kaleckian Model, in: Political Economy. Review of Political Economy and Social Sciences, No. 5, pp. 5-22 Hein, Eckhard (2002): Monetary Policy and Wage Bargaining in the EMU: Restrictive ECB Policies, High Unemployment, Nominal Wage Restraint and Inflation Above the Target, in: Banca Nazionale del Lavoro Quarterly Review, Vol. 55, No. 222, pp. 299-337

Hein, Eckhard (2004): Die NAIRU - eine post-keynesianische Interpretation, in: Intervention. Zeitschrift für Ökonomie, Vol. I, No. I, pp. 43-66

Hein, Eckhard (2006): Interest Rate, Debt and Capital Accumulation - a Kaleckian Approach, in: International Review of Applied Economics, Vol. 20, No. 3, pp. 337-352

Hein, Eckhard (2007): Interest Rate, Debt, Distribution and Capital Accumulation in a PostKaleckian Model, in: Metroeconomica, forthcoming

Hubbard, R. Glenn (1998): Capital Market Imperfections and Investment, in: Journal of Economic Literature, Vol. 36, No. I, pp. 193-225

Kaldor, Nicholas (1957): A Model of Economic Growth, in: The Economic Journal, Vol. 67, No. 268, pp. 59I-624

Kaldor, Nicholas (1970): The New Monetarism, in: Lloyds Bank Review, No. 97, pp. I-I7

Kaldor, Nicholas (1982): The Scourge of Monetarism, Oxford: Oxford University Press

Kaldor, Nicholas (1985): How Monetarism Failed, in: Challenge, Vol. 28, No. 2, pp. 4-I3

Kalecki, Michal (1937): The Principle of Increasing Risk, in: Economica, Vol. 4, No. I6, pp. 440 to pp. 447

Kalecki, Michal (1954): Theory of Economic Dynamics, London: George Allen

Kalecki, Michal (197I): Selected Essays on the Dynamics of the Capitalist Economy, 1933-70, Cambridge: Cambridge University Press

Keynes, John Maynard (1936): The General Theory of Employment, Interest, and Money, in: The Collected Writings of John Maynard Keynes, Vol. VII, I973, London, Basingstoke: Macmillan

Kittel, Bernhard/Traxler, Franz (200I): Lohnverhandlungssysteme und Geldpolitik, in: Wirtschaft und Gesellschaft, Vol. 27, No. I, pp. II-4O

Lavoie, Marc (1984): The Endogenous Flow of Credit and the Post-Keynesian Theory of Money, in: Journal of Economic Issues, Vol. I8, No. 3, pp. 77I-797

Lavoie, Marc (1992): Foundations of Post Keynesian Economic Analysis, Aldershot: Edward Elgar

Lavoie, Marc (1993): A Post-classical View of Money, Interest, Growth and Distribution, in: Mongiovi, Gary / Rühl, Christof (eds.), Macroeconomic Theory: Diversity and Convergence, Cambridge: Cambridge University Press, pp. 3-2I

Lavoie, Marc (1995): Interest Rates in Post-Keynesian Models of Growth and Distribution, in: Metroeconomica, Vol. 46, No. 2, pp. I46-I77

Lavoie, Marc (1996): Horizontalism, Structuralism, Liquidity Preference and the Principle of Increasing Risk, in: Scottish Journal of Political Economy, Vol. 43, No. 3, pp. 275-300

Lavoie, Marc (2002): The Kaleckian Growth Model with Target Return Pricing and Conflict Inflation, in: Setterfield, Mark (ed.), The Economics of Demand-led Growth, Cheltenham: Edward Elgar, pp. 172-188 
Lavoie, Marc (2004): The New Consensus on Monetary Policy Seen From a Post-Keynesian Perspective, in: Lavoie, Marc/Seccareccia, Mario (eds.), Central Banking in the Modern World. Alternative Perspectives, Cheltenham: Edward Elgar, pp. I5-34

Layard, Richard/ Nickell, Stephen / Jackman, Richard (I99I): Unemployment. Macroeconomic Performance and the Labour Market, Oxford: Oxford University Press

Leon-Ledesma, Miguel A. / Thirlwall, Anthony P. (2002): The Endogeneity of the Natural Rate of Growth, in: Cambridge Journal of Economics, Vol. 26, No. 4, pp. 44I-459

Mankiw, N. Gregory (200I): The Inexorable and Mysterious Trade-off Between Inflation and Unemployment, in: The Economic Journal, Vol. III, No. 47I, pp. C45-C6I

McCallum, Bennett (200I): Monetary Policy Analysis in Models Without Money, in: Federal Reserve Bank of St. Louis Review, Vol. 83, No. 4, pp. I45-I60

Meyer, Laurence H. (200I): Does Money Matter?, in: Federal Reserve Bank of St. Louis Review, Vol. 83, No. 5, pp. I-I5

Moore, Basil J. (1988): Horizontalists and Verticalists: The Macroeconomics of Credit Money, Cambridge: Cambridge University Press

Moore, Basil J. (1989): The Endogeneity of Credit Money, in: Review of Political Economy, Vol. I, No. I, pp. 65-93

Palacio-Vera, Alfonso (2005): The >Modern View of Macroeconomics: Some Critical Reflections, in: Cambridge Journal of Economics, Vol. 29, No. 5, pp. 747-767

Pasinetti, Luigi L. (1974): Growth and Income Distribution, Cambridge: Cambridge University Press

Robinson, Joan (1962): Essays in the Theory of Economic Growth, London, New York: Macmillan

Romer, David (2000): Keynesian Macroeconomics Without the LM Curve, in: Journal of Economic Perspectives, Vol. I4, No. 2, pp. I49-169

Rowthorn, Robert E. (1977): Conflict, Inflation and Money, in: Cambridge Journal of Economics, Vol. I, No. 3, pp. 215-239

Rowthorn, Robert E. (1995): Capital Formation and Unemployment, in: Oxford Review of Economic Policy, Vol. II, No. I, pp. 26-39

Rowthorn, Robert E. (1999): Unemployment, Wage Bargaining and Capital-Labour Substitution, in: Cambridge Journal of Economics, Vol. 23, No. 4, pp. 413-425

Sawyer, Malcolm (1985): The Economics of Michal Kalecki, Armonk, New York: M.E. Sharpe

Sawyer, Malcolm (200Ia): The NAIRU: A Critical Appraisal, in: Arestis, Philip/Sawyer, Malcolm (eds.), Money, Finance and Capitalist Development, Cheltenham: Edward Elgar, pp. $220-254$

Sawyer, Malcolm (20orb): Kalecki on Money and Finance, in: European Journal of the History of Economic Thought, Vol. 8, No. 4, pp. 487-508

Sawyer, Malcolm (2002): The NAIRU, Aggregate Demand and Investment, in: Metroeconomica, Vol. 53, No. I, pp. 66-94

Schiantarelli, Fabio (1996): Financial Constraints and Investment: Methodological Issues and International Evidence, in: Oxford Review of Economic Policy, Vol. I2, No. 2, pp. 70-89 
Seccareccia, Mario (1996): Post Keynesian Fundism and Monetary Circulation, in: Deleplace, Ghislain / Nell, Edward J. (eds.), Money in Motion, London: Macmillan, pp. 400-4I6 Seccareccia, Mario (2003): Pricing, Investment and the Financing of Production Within the Framework of the Monetary Circuit: Some Preliminary Evidence, in: Rochon, LouisPhilippe / Rossi, Sergio (eds.), Modern Theories of Money, Cheltenham: Edward Elgar, pp. 173-197

Setterfield, Mark (ed.) (2002): The Economics of Demand-led Growth. Challenging the Supplyside Vision of the Long Run, Cheltenham: Edward Elgar

Setterfield, Mark (2004): Central Banking, Stability and Macroeconomic Outcomes: A Comparison of New Consensus and Post-Keynesian Monetary Macroeconomics, in: Lavoie, Mark/ Seccareccia, Mario (eds.), Central Banking in the Modern World. Alternative Perspectives, Cheltenham: Edward Elgar, pp. 35-56

Snowdon, Brian / Vane, Howard R. (2005): Modern Macroeconomics. Its Origins, Development and Current State, Cheltenham: Edward Elgar

Steindl, Joseph (1952): Maturity and Stagnation in American Capitalism, 2nd edition, New York, London: Monthly Review Press, 1976

Steindl, Joseph (198I): Some Comments on the Three Versions of Kalecki's Theory of the Trade Cycle, in: Lois, J. (ed.), Studies in Economic Theory and Practice, Amsterdam et al.: Elsevier, pp. I25-I33

Stiglitz, Joseph (1997): Reflections on the Natural Rate Hypothesis, in: Journal of Economic Perspectives, Vol. II, No. I, pp. 3-IO

Stockhammer, Engelbert (2004): Is There an Equilibrium Rate of Unemployment in the Long Run?, in: Review of Political Economy, Vol. I6, No. I, pp. 59-77

Taylor, John B. (2000): Teaching Modern Macroeconomics at the Principles Level, in: American Economic Review, Vol. 90, No. 2, pp. 90-94

Taylor, Lance (1985): A Stagnationist Model of Economic Growth, in: Cambridge Journal of Economics, Vol. 9, No. 4, pp. 383-403

Taylor, Lance (2004): Reconstructing Macroeconomics. Structuralist Proposals and Critiques of the Mainstream, Cambridge/Mass., London: Harvard University Press

Walsh, Carl E. (2002): Teaching Inflation Targeting: An Analysis for Intermediate Macro, in: Journal of Economic Education, Vol. 33, No. 4, pp. 333-346 
